\title{
Discothyrea sringerensis (Hymenoptera: Formicidae) a new ant species from India
}

\author{
MERRY ZACHARIAS \& PRIYADARSANAN DHARMA RAJAN \\ Ashoka Trust for Research in Ecology and the Environment (ATREE), No. 659, $5^{\text {th }}$ A main, Hebbal, Bangalore \\ -560 024, India. \\ merryzach@rediffmail.com,priyan@atree.org
}

\begin{abstract}
Discothyrea sringerensis sp. nov. is described and is the first record of this genus from South India. The other known species of Discothyrea are scattered within the tropics and the temperate zones of the world. Based on workers, D. sringerensis is most similar to the species described from Malaysia and Australia characterised by 10 -segmented antennae.
\end{abstract}

Key words: Discothyrea, Proceratiinae, Formicidae, Western Ghats, India

\section{Introduction}

The range of Discothyrea lies predominantly within the tropics and warm temperate parts of the Southern Hemisphere (Brown 1958; Bolton 1995; Kubota \& Terayama 1999). The only known species from India is Discothyrea stumperi from Meghalaya (de Andrade 1998). Baroni Urbani (1977), after examining specimens collected by myrmecologists after an expedition to South India and Sri Lanka, mentions no encounter of Discothyrea from these regions.

Discothyrea are small rare ants mostly encountered in the litter where they are thought to be specialist predators on arthropod eggs. Due to its small size, inconspicuous nests, death-feigning habits and cryptobiotic tendencies, Discothyrea is relatively rarely collected and little is known of its habits (Brown 1958).

The species described here is the first report of this genus from the Western Ghats. The new species shows close affinity to the Malaysian species Discothyrea bryanti Wheeler and to the Australian species Discothyrea velutina Wheeler, both characterised by 10 -segmented antennae. 
Discothyrea Roger, 1863: 176.

Type species: Discothyrea testacea Roger, 1863, by monotypy.

Pseudosysphincta Arnold, 1916: 161.

Type species: Pseudosysphincta poweri Arnold, 1916 [synonymised by Brown 1958].

Prodiscothyrea Wheeler, 1916: 33.

Type species: Prodiscothyrea velutina Wheeler, 1916 [synonymised by Brown 1958].

Pseudosphincta Wheeler, 1922: 645, 762 [variant spelling of Pseudosysphincta].

General diagnosis. Small stocky ants, notable for the exaggerated enlargement of the apical antennal segment. The antennae are 6-12 segmented. Mandibles edentate and overhung by a projecting clypeus. Alitrunk is short and sutureless dorsally (Brown 1958; Bolton 1994).

\section{Discothyrea sringerensis sp. nov.}

Description of holotype. Worker (Fig. 1). Total body length $3.05 \mathrm{~mm}$, Head length $0.80 \mathrm{~mm}$, Head width $0.54 \mathrm{~mm}$, Cephalic Index (HW/HL x 100) 67 , scape length $0.46 \mathrm{~mm}$, petiole height $0.25 \mathrm{~mm}$, dorsal petiole length $0.10 \mathrm{~mm}$, dorsal petiole width $0.28 \mathrm{~mm}$.
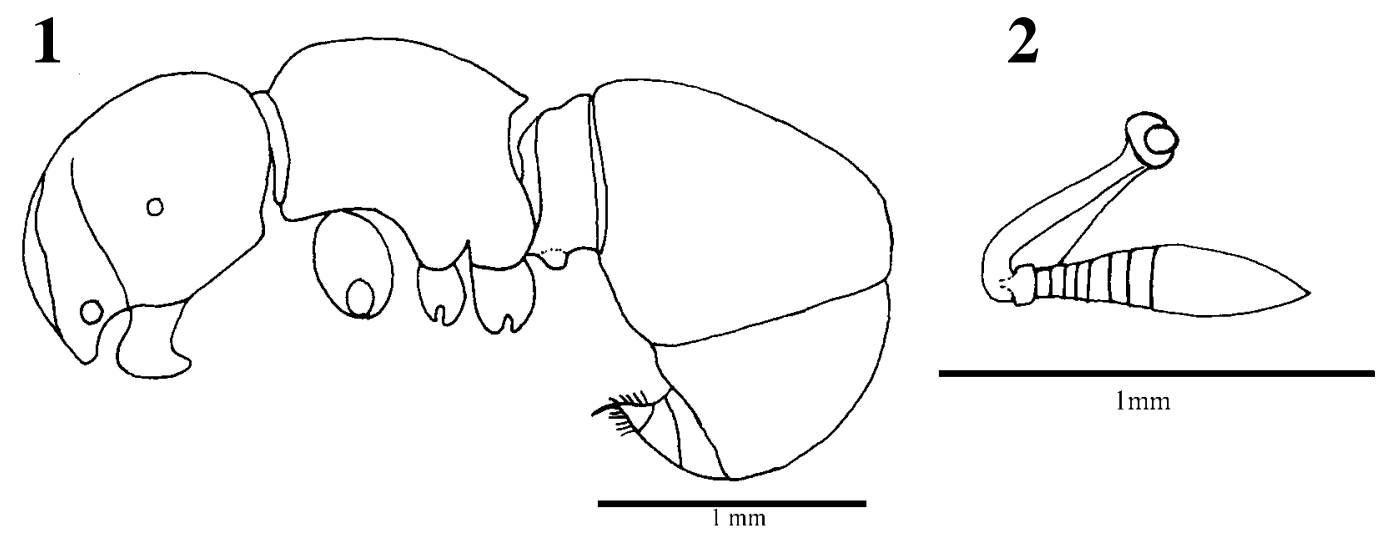

FIGURES 1-2. Discothyrea sringerensis sp. nov. 1, lateral view; 2, ten segmented antennae depicting enlarged apical antennal segment.

Head from front broadly oval with almost straight posterior margin. Clypeus extending forward so that it overhangs the rear part of the mandibles when they are closed. Anterior margin of the clypeus crenulated. Palp formula 5, 4. Antennae 10 segmented; scape massively clavate. Second antennal segment $0.06 \mathrm{~mm}$ long, sub globular. $3^{\text {rd }}$ to $6^{\text {th }}$ antennal segments almost equal in length (each $0.07 \mathrm{~mm}$ ). $7^{\text {th }}-9^{\text {th }}$ antennal segments distinctly 
wider than long. Apical antennal segment large, twice as long as wide (Fig. 2). Depressed

scrobal area distinct. Frontal carinae extending back about two-thirds the length of the head, dilated and horizontally flattened in the middle. Posterior end of frontal lobe opened and rounded anteroposteriorly and continuous with the regular convex surface of the head. Eyes placed on side of head nearer to the base of the mandibles than to the posterior border of the head, composed of at least 12 ommatidia in each with hairs in between the ommatidia.

Mesosoma stout, with blunt, rounded humeral angles. Propodeum with more distinct propodeal teeth. Legs stout, spur of posterior leg pectinate, spur on middle leg absent.

Petiole in the form of a thick disc, 2.80 times broader than long dorsally and with two low rims running along the anterior and posterior margins of the petiole. The petiole is attached over a large portion of its posterior surface to the gaster and is lower in height than the gaster. In profile, petiole with weakly concave dorsal margin and a sloping anterior surface. Subpetiolar process on the ventral margin, a prominent compressed translucent tooth.

Head, mesosoma and abdomen coarsely punctate. The scrobal depressions sparsely punctate with horizontal striations that extend from the lateral walls of the frontal lobe.

The entire body densely clothed with short suberect to erect whitish pubescence, which is slightly shorter on the head and antennae.

Body colour reddish brown with mandibles, antennae, legs and tip of gaster yellowish brown.

Holotype. Worker, India, Karnataka, Kumbarakodu Reserve Forest of Sringeri $\left(13^{\circ} 29^{\prime} 19^{\prime \prime} \mathrm{N}\right.$ and $75^{\circ} 11^{\prime}$ 52” E). 26. iii. 2001. P.A. Sinu. Collected from evergreen forest leaf litter using pitfall trap.

Paratypes. 6 workers, data same as holotype.

Type repository. Holotype will be deposited at the Museum of the Zoological Survey of India, Calcutta and the paratypes will be deposited at the British Museum of Natural History and Insect Museum of Ashoka Trust for Research in Ecology and the Environment (ATREE), Bangalore, Karnataka, India.

Etymology. The species name sringerensis indicates its type locality.

\section{Remarks}

This species is similar to one Malaysian species, Discothyrea bryanti Wheeler, and one Australian species, Discothyrea velutina, in the following characteristics: (1) Antennae with 10 segments, and (2) absence of spur in middle tibiae. Discothyrea sringerensis is similar to D. bryanti in the following characters: (1) petiole with a prominent compressed translucent tooth on its ventral surface, and (2) more distinct propodeal teeth. However, the Indian species differs from $D$. bryanti in (1) the funiculus being distinctly longer than the antennal scape (Fig. 2), (2) the petiole being less than four times as broad as long, and 

sis shows some affinity to D. velutina in the following characters: (1) cheeks without a blunt tooth in front of eyes, and (2) funiculus longer than scape. However, it differs from D. velutina in the following characters: (1) distinct propodeal teeth, (2) petiole with a prominent compressed translucent tooth on its ventral surface, and (3) palp formula 5,4 (D. velutina has a palp formula of 4,4$)$. The maxillary and labial palps are variously segmented, according to species (Brown 1958). The palp formula of D. bryanti is unavailable.

\section{Acknowledgements}

We express our gratitude to P. A. Sinu for lending us the specimens, which enabled us to write this paper. One of us (DRP) is thankful to Indian Council of Agricultural Research (ICAR) for support under National Agricultural Technology Program (NATP/CGP-III/ 386). We thank John Longino, Donat Agosti, Steve Shattuck and an anonymous reviewer for their comments that helped to improve our manuscript.

\section{References}

Andrade (de) M.L. (1998) First fossil records of the ant genus Discothyrea in Dominican and Mexican amber (Hymenoptera, Formicidae). Fragmenta entomologica, 30(1), 201-214.

Arnold, G. (1916) A monograph of the Formicidae of South Africa. Part 2. (Ponerinae; Dorylinae). Annals of the South African Museum, 14, 159-270.

Baroni Urbani. (1977) Discothyrea stumperi n. sp. du Bhoutan, premier representant du genre dans le subcontinent Indien (Hymenoptera: Formicidae). Archives Institut Grand-Ducal de Luxembourg, 37, 97-100.

Bolton, B. (1994) Identification Guide to the Ant Genera of the World. Harvard University Press, Cambridge, MA, 222pp.

Bolton, B. (1995) A taxonomic and zoogeographical census of the extant ant taxa (Hymenoptera: Formicidae). Journal of Natural History, 29, 1037-1056.

Brown, W.L. Jr. (1958) Contributions toward a reclassification of the Formicidae. II Tribe Ectatommini. Bulletin of the Museum of Comparative Zoology, Harvard, 118, 175-362.

Kubota, M. \& Terayama, M. (1999) A description of a new species of the genus Discothyrea Roger from Ryukyus, Japan (Hymenoptera: Formicidae). Memoirs of the Myrmecological Society of Japan, 1, 1-5.

Roger, J. (1863) Die neu aufgeführten Gattungen und Arten meines Formiciden-Verzeichnisses, nebst Ergänzung einiger früher gegeben Beschreibungen. Berliner Entomologische Zeitschrift, 7, 131-214.

Wheeler, W.M. (1916) Prodiscothyrea, a new genus of Ponerine ants from Queensland. Transactions of the Royal Society of South Australia, 40, 33-37.

Wheeler, W.M. (1922) The ants of the Belgian Congo. Bulletin of the American Museum of Natural History, 45, 1-1139. 